\title{
Mediated Electrochemical Reduction of Iron (Oxyhydr-)Oxides under Defined Thermodynamic Boundary Conditions
}

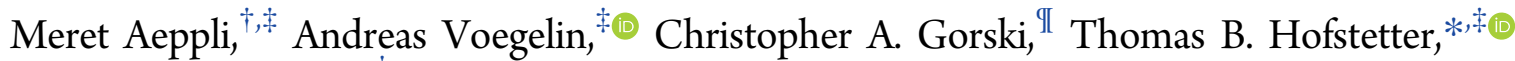 \\ and Michael Sander*, ${ }^{*}$
}
${ }^{\dagger}$ Institute of Biogeochemistry and Pollutant Dynamics, Swiss Federal Institute of Technology (ETH), 8092 Zurich, Switzerland
${ }^{*}$ Swiss Federal Institute of Aquatic Science and Technology (Eawag), 8600 Duebendorf, Switzerland

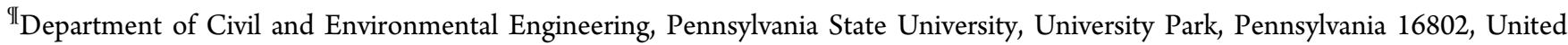 States

\section{Supporting Information}

ABSTRACT: Iron (oxyhydr-)oxide reduction has been extensively studied because of its importance in pollutant redox dynamics and biogeochemical processes. Yet, experimental studies linking oxide reduction kinetics to thermodynamics remain scarce. Here, we used mediated electrochemical reduction (MER) to directly quantify the extents and rates of ferrihydrite, goethite, and hematite reduction over a range of negative reaction free energies, $\Delta_{\mathrm{r}} G$, that were obtained by systematically varying $\mathrm{pH}$ (5.0 to 8.0$)$, applied reduction potentials $(-0.53$ to $-0.17 \mathrm{~V}$ vs $\mathrm{SHE})$, and $\mathrm{Fe}^{2+}$ concentrations (up to $40 \mu \mathrm{M}$ ). Ferrihydrite reduction was complete and fast at all tested $\Delta_{\mathrm{r}} G$ values, consistent with its comparatively low thermodynamic stability. Reduction of the thermodynamically more stable goethite and hematite changed from complete and fast to incomplete and slow as $\Delta_{\mathrm{r}} G$ values became less negative. Reductions at intermediate $\Delta_{\mathrm{r}} G$ values showed negative linear correlations between the natural logarithm of the reduction rate constants and $\Delta_{\mathrm{r}} G$. These correlations imply that thermodynamics controlled goethite and hematite reduction rates. Beyond allowing to study iron oxide reduction under defined thermodynamic conditions, MER can also be used to capture changes in iron oxide reducibility during phase transformations, as shown for $\mathrm{Fe}^{2+}$-facilitated transformation of ferrihydrite to goethite.

\section{INTRODUCTION}

Ferric iron (oxyhydr-)oxides are predominant redox-active minerals in many natural and engineered systems. ${ }^{1-3}$ These minerals include ferrihydrite, goethite, and hematite and, for simplicity, are subsequently referred to as iron oxides. Redox reactions involving iron oxides influence the (bio)availability of nutrients ${ }^{4,5}$ and trace elements, ${ }^{6,7}$ the fate of pollutants, ${ }^{8,9}$ and the cycling of major and minor elements. ${ }^{10,11}$ For instance, iron oxides can serve as terminal electron acceptors in anaerobic microbial respiration ${ }^{12-14}$ and can stimulate interspecies electron transfer. ${ }^{15-17}$ Reduction of iron oxides may lead to their dissolution and the simultaneous release of associated trace elements. ${ }^{18,19}$ Ferrous iron formed during the reduction of iron oxides may associate with the oxides and thereby become a potent reductant for many contaminants, including toxic metals and metalloids, ${ }^{20-22}$ radionuclides, ${ }^{23,24}$ and organic compounds. $^{25,26}$

The importance of iron oxide redox reactions in biogeochemical processes and pollutant dynamics has led to considerable research efforts directed toward characterizing the redox properties and reactivities of these minerals. Such characterizations have proven challenging, however, because electron transfer to iron oxides is linked to a series of concurrent reactions, ${ }^{27}$ including the association of the formed $\mathrm{Fe}^{2+}$ with the iron oxide surface, ${ }^{28,29}$ interfacial electron transfer followed by electron transfer in the crystal lattice of the iron oxide, ${ }^{30-32}$ atom exchange, ${ }^{33-36}$ and mineral recrystallization reactions. ${ }^{37-40}$ The resulting redox chemistry of the oxide $\mathrm{Fe}^{3+} /$ $\mathrm{Fe}^{2+}$ couple made it difficult to interpret iron oxide reduction data obtained from batch experiments with poor control of the thermodynamic boundary conditions for reduction. These boundary conditions include the reduction potential, $E_{\mathrm{H}}$, the solution $\mathrm{pH}$, and the $\mathrm{Fe}^{2+}$ activity. Research on iron oxide redox chemistry would benefit from an experimental system that allows controlling and systematically altering these boundary conditions and, at the same time, monitoring electron transfer to and from iron oxides.

We and others have recently employed mediated amperometric analysis to characterize the redox properties and

Received: August 28, 2017

Revised: December 1, 2017

Accepted: December 4, 2017

Published: December 4, 2017 
reactivities of organic and mineral geochemical phases, including natural organic matter, ${ }^{41,42}$ pyrogenic carbonaceous materials, ${ }^{43}$ iron-containing minerals, ${ }^{44-48}$ as well as of sediments containing more than one redox-active constituent. $^{49,50}$ This electrochemical approach offers the unique capability to study electron transfer to and from geochemical phases under well-controlled thermodynamic boundary conditions defined by the reduction potential applied to the working electrode and the $\mathrm{pH}$ of the solution in the electrochemical cell. Electron transfer between the working electrode and the geochemical phase added to the cell is facilitated by dissolved electron transfer mediators. The use of mediators is critical to overcome kinetic artifacts typically encountered in nonmediated measurements that arise from sluggish electron transfer between the working electrode and the geochemical phase. ${ }^{51,52}$ Depending on whether the cells are operated under reducing or oxidizing conditions relative to the phase added, mediated electrochemical reduction (MER) and oxidation (MEO) result in reductive and oxidative current peaks. In the past, we and others exclusively used MER and MEO to quantify the capacities of geochemical phases to accept and donate electrons by integrating the reductive or oxidative current peaks (e.g. refs 41-50). However, a second feature of mediated electrochemical analysis has not yet been systematically explored: the measured currents correspond to the rates at which electrons are transferred across the working electrode and may thus also provide a direct measure for the rates at which electrons are transferred to and from a geochemical phase. $^{51}$

The goal of this work was to assess the applicability of MER to quantify both extents and rates of electron transfer to iron oxides under controlled thermodynamic boundary conditions. We focused on iron oxide reduction because this reaction has well-constrained standard reduction potentials and because we can readily calculate the effects of the reduction product, $\mathrm{Fe}^{2+}$, on system thermodynamics. To reach this goal, we performed MER experiments with three iron oxides commonly found in the environment, namely ferrihydrite, goethite, and hematite. We added these oxides in suspended form to MER cells that we operated at different reduction potentials applied to the working electrode, $E_{\mathrm{H}}^{\mathrm{MER}}$, and at different solution $\mathrm{pH}$. Furthermore, we systematically altered the activity of dissolved $\mathrm{Fe}^{2+}$ in the cell solutions during iron oxide reduction. These variations resulted in a wide range of negative reaction free energies, $\Delta_{\mathrm{r}} G$, for iron oxide reduction. The work had three specific objectives. First, we tested whether the selected iron oxides are reducible during MER and qualitatively assessed the effect of $\Delta_{\mathrm{r}} G$ on reductive current responses. Second, we evaluated the capabilities of MER to relate extents and rates of iron oxide reduction to $\Delta_{\mathrm{r}} G$ quantitatively. Third, we assessed whether MER can be used to characterize changes in the reducibility of iron oxides under conditions that favor phase transformations of iron oxides.

\section{MATERIALS AND METHODS}

Solutions and Suspensions. All solutions and suspensions were prepared with deionized water (resistivity $>18.2 \mathrm{M} \Omega \cdot \mathrm{cm}$, Barnstead Nanopure Diamond Water Purification System). Oxygen-free solutions (with and without $\mathrm{pH}$ buffers) were prepared by heating them to $80^{\circ} \mathrm{C}$ and purging them with ultrahigh purity $\mathrm{N}_{2}(99.999 \%)$ for at least $2 \mathrm{~h}$. Oxygen was removed from iron oxide suspensions by purging them with ultrahigh purity $\mathrm{N}_{2}(99.999 \%)$ for $3 \mathrm{~h}$ without heating. All MER measurements were conducted in aqueous solutions containing $\mathrm{pH}$ buffers (all $0.01 \mathrm{M}$; acetic acid $\left(\mathrm{pK}_{\mathrm{a}}=4.75\right)$ for $\mathrm{pH} 5$; 2- $(\mathrm{N}$ morpholino)ethanesulfonic acid (MES; $\left.p \mathrm{~K}_{a}=6.15\right)$ for $\mathrm{pH} 6-$ 6.5; 3-morpholinopropane-1-sulfonic acid (MOPS; $p \mathrm{~K}_{\mathrm{a}}=7.2$ ) for $\mathrm{pH} 6.75 ; 2$-[4-(2-hydroxyethyl)piperazin-1-yl]ethanesulfonic acid (HEPES; $p \mathrm{~K}_{\mathrm{a}}=7.5$ ) for $\mathrm{pH} 7-8$ ) and $0.1 \mathrm{M} \mathrm{KCl}$ as electrolyte.

Chemicals and Iron Oxides. A list of all chemicals used can be found in the Supporting Information (SI), Section S1. 6line ferrihydrite, goethite, and hematite were synthesized according to established protocols. ${ }^{53}$ SI Section S2 provides details on the synthesis and characterization of the iron oxides.

Mediated Electrochemical Reduction. Iron oxide reductions were carried out in electrochemical cells positioned in a $\mathrm{N}_{2}$-atmosphere glovebox (Unilab 2000, MBraun, Germany) $\left(\mathrm{O}_{2}<2 \mathrm{ppm}\right)$. The electrochemical cells consisted of $9 \mathrm{~mL}$ glassy carbon cylinders (GAZ 1, HTW, Germany) that served simultaneously as reaction vessels and working electrodes (WE). The solution in each WE cylinder was stirred continuously with a Teflon-coated stir bar and a stir plate positioned below the cell. $E_{\mathrm{H}}^{\mathrm{MER}}$ were measured against $\mathrm{Ag}$ / $\mathrm{AgCl}$ reference electrodes (Re1B, ALS, Japan) but are reported herein versus the standard hydrogen electrode (SHE). Each cell contained a platinum wire counter electrode that was separated from the WE compartment by a porous glass frit (PORE E tubes; ACE glass). The cells were controlled by two eightchannel potentiostats (models 1000B and 1000C, $\mathrm{CH}$ Instruments). ${ }^{45,46}$ Current data was collected with a $5 \mathrm{~s}$ sampling frequency.

We determined both the extents and rates of iron oxide reduction at different $E_{\mathrm{H}}^{\mathrm{MER}}$, solution $\mathrm{pH}$, and $\mathrm{Fe}^{2+}$ activities. While we separately discuss the extents and rates of oxide reduction, the data originated from the same MER experiments. These experiments were performed as follows. After filling the WE cylinder and counter electrode compartment with a $\mathrm{pH}$ buffered solution, we applied a defined and constant $E_{\mathrm{H}}^{\mathrm{MER}}$ to the WE. Once the background current had stabilized at low values (i.e., $<3 \mu \mathrm{A}$ ), one of several electron transfer mediators was added to the WE cylinder from a $10 \mathrm{mM}$ mediator stock solution: 1,1'-bis(cyanomethyl)-4,4'-bipyridyl (cyanomethyl viologen, standard reduction potential $E_{\mathrm{H}}^{0}=-0.140 \mathrm{~V}$ ) was used at $E_{\mathrm{H}}^{\mathrm{MER}}$ from $-0.17 \mathrm{~V}$ to $-0.305 \mathrm{~V}, 1,1^{\prime}$-ethylene-2,2' bipyridyl (diquat, $E_{\mathrm{H}}^{0}=-0.35 \mathrm{~V}$ ) at $E_{\mathrm{H}}^{\mathrm{MER}}$ from $-0.35 \mathrm{~V}$ to $-0.485 \mathrm{~V}$, and $1,1^{\prime}$-trimethylene-2,2' -bipyridyl (triquat, $E_{\mathrm{H}}^{0}=$ $-0.54 \mathrm{~V}$ ) at an $E_{\mathrm{H}}^{\mathrm{MER}}$ of $-0.53 \mathrm{~V}$. We chose these viologens as mediators because they are structurally related to each other and undergo fully reversible and $\mathrm{pH}$-independent one electron transfer reactions. Similar viologen mediators were previously used in nonelectrochemical iron oxide reduction experiments. ${ }^{54-56}$ The iron oxide reductions were carried out at a constant concentration of reduced mediator of $0.255 \mathrm{mM}$, which was approximately 10 times higher than the total iron concentration in the WE cylinder after the first addition of iron oxide suspension. At this concentration ratio of reduced mediator to oxide $\mathrm{Fe}$, the maximum iron oxide reduction rates measured in MER were independent of the mediator concentration (SI Section S3). To obtain the same reduced mediator concentration in all experiments, we adjusted the total mediator amount added to the cells to the potential offsets between applied $E_{\mathrm{H}}^{\mathrm{MER}}$ and mediator $E_{\mathrm{H}}^{0}$ (resulting in different concentration ratios of oxidized to reduced mediator species in the cells). Addition of iron oxide suspension to the cell resulted in electron transfer from the reduced mediator to the iron 
oxide, which lead to an increase in the concentration ratio of oxidized to reduced mediator in the cell. The formed oxidized mediator molecules were immediately re-reduced at the WE, resulting in reductive current peaks that were analyzed as described below.

For standard MER experiments, each mediator was transferred to the cell in three separate additions prior to the iron oxide additions and in two further additions after the oxide additions (see SI Section S4 for an illustration of the spiking scheme). All mediator additions were sufficiently spaced apart for baseline separation of the resulting reductive current peaks. The first mediator addition resulted in a reduced mediator concentration in the cell of $0.218 \mathrm{mM}$. The following two mediator additions had smaller, yet identical volumes and each increased the reduced mediator concentration by $0.018 \mathrm{mM}$ (total reduced mediator concentration after the three additions: $0.255 \mathrm{mM}$ ). The three mediator additions were followed by triplicate additions of the same iron oxide suspension to the electrochemical cell (see next paragraph). Finally, following the oxide additions, we repeated the two smaller mediator additions, after which the final reduced mediator concentration in the cell had increased to approximately $0.283 \mathrm{mM}$. The reductive current peaks in response to the four small mediator additions served to determine the rate constants of mediator reduction in each individual cell setup. These rate constants were used to account for the effect of slight differences in the responsiveness of the electrochemical cell setups on iron oxide reduction rate constants (see below).

Iron oxide suspensions were added to the electrochemical cells in three sequential $50 \mu \mathrm{L}$ aliquots from iron oxide stock suspensions containing $134 \pm 4,142 \pm 1$, and $127 \pm 1 \mathrm{mg}_{\mathrm{Fe}}$ $\mathrm{L}^{-1}$ of ferrihydrite, goethite and hematite, respectively. These iron concentrations were independently quantified using the phenanthroline method after iron oxide dissolution in $6 \mathrm{M} \mathrm{HCl}$ and iron reduction by ascorbic acid. ${ }^{57}$ The additions of the iron oxide suspensions were sufficiently spaced apart to ensure baseline separation of the resulting reductive current peaks. The reductive current responses to the first iron oxide additions served to quantify extents and rates of iron oxide reduction at the given experimental $E_{\mathrm{H}}^{\mathrm{MER}}$ and solution $\mathrm{pH}$. The current responses to the second and third iron oxide additions served to investigate the effect of accumulating $\mathrm{Fe}^{2+}$ in the electrochemical cell on the extents and rates of iron oxide reduction.

Iron Oxide Transformation Experiment. We ran duplicate batch reactors $\left(400 \mathrm{~mL}\right.$ each) in a $\mathrm{N}_{2}$ atmosphere glovebox (Unilab 2000, MBraun, Germany) to carry out ferrihydrite transformation in the presence of $\mathrm{Fe}^{2+}$. The transformation was initiated by addition of $\mathrm{FeCl}_{2}$ (final solution concentration: $1 \mathrm{mM}$ ) to a ferrihydrite suspension $(10 \mathrm{mM}$ $\left.\mathrm{Fe}^{3+}\right)$. The transformation was terminated $15 \mathrm{~d}$ after $\mathrm{Fe}^{2+}$ addition. During the transformation, the iron oxide suspension was continuously stirred using an overhead stirrer (Unistirrer $\mathrm{OH} 2$, LLG, Germany) and the $\mathrm{pH}$ of the suspension was kept constant at $\mathrm{pH} 7.0$ using an automated $\mathrm{pH}$-stat titrator (titration of $70 \mathrm{mM} \mathrm{KOH}$ with a 907 Titrando, Metrohm, Switzerland). The initial and final materials were characterized using X-ray diffraction, transmission electron microscopy and MER (see SI Section S5 for details). Duplicate MER experiments were performed for each sample at eight different $\mathrm{pH}$ (i.e., $\mathrm{pH}$ 5.00, 5.50, 6.00, 6.25, 6.50, 6.75, 7.00, and 7.25) and at constant $E_{\mathrm{H}}^{\mathrm{MER}}=-0.35 \mathrm{~V}$ as described in the previous section except that we only added a single $20 \mu \mathrm{L}$ aliquot of the iron oxide suspension to the MER cell.
Data Analysis. The number of electrons transferred to the iron oxides, $q\left[\mathrm{~mol}_{\mathrm{e}}^{-}\right]$, was quantified by integration of the reductive current peak that resulted from iron oxide additions to the MER cell according to eq $1 .{ }^{45}$

$$
q\left(t_{\text {end }}\right)=\frac{1}{F} \int_{t_{0}}^{t_{\text {end }}} I(\mathrm{t}) \mathrm{d} t
$$

where $I(\mathrm{t})[\mathrm{A}]$ is the baseline-corrected reductive current, $F$ is the Faraday constant, and $t_{0}$ and $t_{\text {end }}[\mathrm{s}]$ denote the initial and final integration boundaries for each current peak. Current responses were corrected for the background current described by the fit of a spline function (using Igor Pro, WaveMetrics) through background current points that we selected manually. Peak integration and determination of the maximum current response, $I_{\max }$, were performed using Matlab (MathWorks). The Matlab code used for data analysis is provided in SI Section S6.

Observed rate constants for iron oxide reduction, $k_{\mathrm{obs}}\left[\mathrm{s}^{-1}\right]$, were obtained from the current responses in MER experiments that resulted in complete iron oxide reduction according to eq $2^{51}$

$$
-k_{\mathrm{obs}} \cdot t=\ln \left(\frac{\mathrm{Fe}_{t}^{3+}}{\mathrm{Fe}_{t_{0}}^{3+}}\right)=\ln \left(1-\frac{q(t)}{q\left(t_{\text {end }}\right)}\right)=\ln \left(1-\frac{\frac{1}{F} \cdot \int_{t_{0}}^{t} I(t) \mathrm{d} t}{q\left(t_{\text {end }}\right)}\right)
$$

where $t_{0}$ and $t[\mathrm{~s}]$ are the time of iron oxide addition to the MER cell and the time during oxide reduction, respectively, $\mathrm{Fe}_{t}^{3+} / \mathrm{Fe}_{t_{0}}^{3+}[1]$ is the fraction of the initially added ferric iron that remains in the electrochemical cell at time $t$, and $I(t)[\mathrm{A}]$ is the time-dependent background-corrected reductive current response. We determined $k_{\mathrm{obs}}$ from the slope of a linear regression line fitted to the reductive current response plotted as $\ln \left(\mathrm{Fe}_{t}^{3+} / \mathrm{Fe}_{t_{0}}^{3+}\right)$ versus time using Matlab (MathWorks; see SI Section S6 for the Matlab code). This linear regression was carried out on current data collected between the time point of the maximum reductive current and the time point at which $95 \%$ of the added $\mathrm{Fe}^{3+}$ was reduced (see SI Section S7 for the fraction of $\mathrm{Fe}^{3+}$ reduced until the time of $\left.I_{\max }\right)$. We note that eq 2 corresponds to the analytical solution of a general rate law for mineral dissolution introduced by Christoffersen and Christoffersen ${ }^{58}$ and Postma ${ }^{59}$ for the case when reduction rates are unaffected by changes in size, morphology and reactive site density of iron oxide particles during reduction (see SI Section S8 for details). This assumption was justified given that all current data was well described by eq 2 . Furthermore, we show in SI Sections S8 and S9 that eq 2 and the general rate law for dissolution allowing for changes in iron oxide reactivity during the reduction resulted in very similar iron oxide reduction rate constants.

The reduction rate constants for the mediators, $k_{\mathrm{obs}}^{\mathrm{med}}\left[\mathrm{s}^{-1}\right]$, were obtained from the reductive current peaks in response to the second to the fourth mediator additions using a modified version of eq 2 (i.e., $\ln \left(\operatorname{med}_{\text {red }}(t) / \operatorname{med}_{\text {red }}\left(t_{0}\right)\right)$ instead of $\ln \left(\mathrm{Fe}_{t}^{3+} / \mathrm{Fe}_{t_{0}}^{3+}\right)$ and $k_{\mathrm{obs}}^{\mathrm{med}}$ instead of and $\left.k_{\mathrm{obs}}\right)$. We determined $k_{\mathrm{obs}}^{\mathrm{med}}$ for two reasons. First, the $k_{\mathrm{obs}}^{\mathrm{med}}$ values defined an experimental limit for $k_{\mathrm{obs}}$ values. In MER experiments that resulted in $k_{\mathrm{obs}} \approx k_{\mathrm{obs}}^{\mathrm{med}}$, reductive currents were controlled by mediator re-reduction and not by transfer of electrons from the mediator to the iron oxide. Second, $k_{\mathrm{obs}}^{\text {med }}$ values served to capture differences in the responsiveness among individual electrochemical cells that resulted from small changes in the cell 

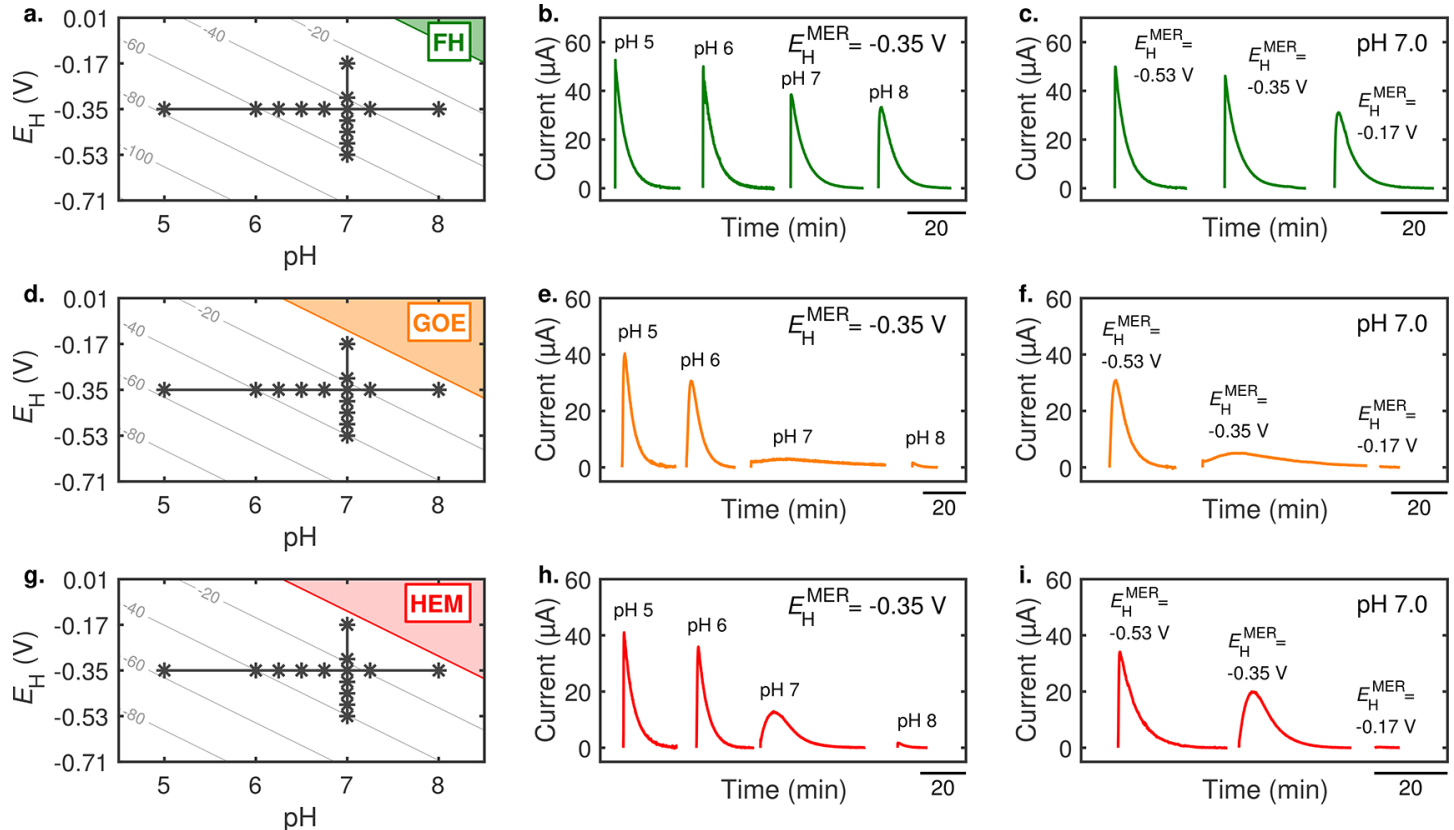

Figure 1. a., d., g. $E_{\mathrm{H}}-\mathrm{pH}$ diagrams for ferrihydrite $(\mathrm{FH})$, goethite (GOE) and hematite (HEM) were drawn using the Nernst equation (eq 8$)$ and a ferrous iron concentration of $1 \mu \mathrm{M}$ (see Materials and Methods for details). The colored areas represent conditions at which the iron oxides are thermodynamically stable. The $E_{\mathrm{H}}^{\mathrm{MER}}-\mathrm{pH}$ conditions that were chosen for this study are shown as black stars. The gray contour lines mark conditions of identical reaction free energies, $\Delta_{\mathrm{r}} G$, and are labeled with the respective values in $\mathrm{kJ} \mathrm{mol}^{-1}$. b., e., h. Current responses measured during the reduction of $\mathrm{FH}, \mathrm{GOE}$ and HEM at varying solution $\mathrm{pH}$ and c., f., i. at varying potentials applied to the working electrode of the electrochemical cell, $E_{\mathrm{H}}^{\mathrm{MER}}$.

setups (e.g., stirring speed and/or depth of the counter electrode compartment in the cell). Because the responsiveness of an electrochemical cell equally affected mediator and iron oxide reduction rates, we used $k_{\mathrm{obs}}^{\mathrm{med}}$ values to correct absolute $k_{\text {obs }}$ values for differences in cell reactivity according to eq 3 .

$$
k_{\mathrm{obs}}^{*}=k_{\mathrm{obs}} \cdot \frac{k_{\mathrm{obs}, \mathrm{av}}^{\mathrm{med}}}{k_{\mathrm{obs}}^{\mathrm{med}}}
$$

where $k_{\mathrm{obs}}^{*}\left[\mathrm{~s}^{-1}\right]$ is the corrected observed rate constant for iron oxide reduction, and $k_{\mathrm{obs} \text {, av }}^{\mathrm{med}}\left[\mathrm{s}^{-1}\right]$ is the averaged mediator reduction rate constant measured for all MER experiments in which the same mediator species was used. We note that variations in $k_{\mathrm{obs}}^{\mathrm{med}}$ were small for all three mediators $\left(k_{\mathrm{obs}, \mathrm{mv}}^{\mathrm{med}}=\right.$ $4.03 \cdot 10^{-3} \pm 0.40 \cdot 10^{-3} \mathrm{~s}^{-1}$ for cyanomethyl viologen, $4.56 \cdot$ $10^{-3} \pm 0.63 \cdot 10^{-3} \mathrm{~s}^{-1}$ for diquat and $3.87 \cdot 10^{-3} \pm 0.33 \cdot 10^{-3}$ $\mathrm{s}^{-1}$ for triquat).

For all iron oxides, duplicate MER experiments were carried out simultaneously in two separate electrochemical cells. Reported $q$ and $k_{\mathrm{obs}}^{*}$ are the averages of the duplicate measurements (error bars depict deviations of single measurements from the mean). These averages were determined individually for each of the three sequential iron oxide additions, resulting in separate $q$ and $k_{\mathrm{obs}}^{*}$ for the first, second and third iron oxide addition.

Thermodynamic Calculations. We used the stoichiometries and $\mathrm{pH}$-dependencies of the reductive dissolution of ferrihydrite (expressed for simplicity as $\mathrm{Fe}(\mathrm{OH})_{3}$ below), goethite $(\alpha-\mathrm{FeOOH})$, and hematite $\left(\alpha-\mathrm{Fe}_{2} \mathrm{O}_{3}\right)$, shown in reaction eqs 4 to 6 , to calculate reaction free energies, $\Delta_{\mathrm{r}} G[\mathrm{~kJ}$ $\left.\mathrm{mol}^{-1}\right]$.

$$
\mathrm{Fe}(\mathrm{OH})_{3}+\mathrm{e}^{-}+3 \mathrm{H}^{+} \rightleftharpoons \mathrm{Fe}^{2+}+3 \mathrm{H}_{2} \mathrm{O}
$$

$$
\begin{aligned}
& \alpha-\mathrm{FeOOH}+\mathrm{e}^{-}+3 \mathrm{H}^{+} \rightleftharpoons \mathrm{Fe}^{2+}+2 \mathrm{H}_{2} \mathrm{O} \\
& \alpha-\mathrm{Fe}_{2} \mathrm{O}_{3}+2 \mathrm{e}^{-}+6 \mathrm{H}^{+} \rightleftharpoons 2 \mathrm{Fe}^{2+}+3 \mathrm{H}_{2} \mathrm{O}
\end{aligned}
$$

$\Delta_{\mathrm{r}} G$ was calculated from the difference between the reduction potential of the iron oxide under the experimental conditions (i.e., $\mathrm{pH}$ and $\mathrm{Fe}^{2+}$ concentration) in the electrochemical cell, $E_{\mathrm{H}}^{\text {oxide }}$, and $E_{\mathrm{H}}^{\mathrm{MER}}$ according to eq 7 .

$$
\Delta_{\mathrm{r}} G=-n F \cdot\left(E_{\mathrm{H}}^{\text {oxide }}-E_{\mathrm{H}}^{\mathrm{MER}}\right)
$$

where $n$ is the number of transferred electrons $(n=1$ for the reduction of $\mathrm{Fe}^{3+}$ to $\mathrm{Fe}^{2+}$ ) and $F$ is the Faraday constant. $E_{\mathrm{H}}^{\text {oxide }}$ was calculated from the Nernst equation (eq 8).

$$
E_{\mathrm{H}}^{\text {oxide }}=E_{\mathrm{H}}^{0}-\frac{R T}{n F} \cdot \ln \frac{\left\{\mathrm{Fe}_{\mathrm{aq}}^{2+}\right\}^{\mathrm{m}_{\mathrm{Fe}}{ }^{2+}}}{10^{-\mathrm{m}_{\mathrm{H}}+\mathrm{pH}}}
$$

where $R$ is the gas constant, $T(=298.15 \mathrm{~K})$ is the absolute temperature at which MER experiments were conducted, and $m_{\mathrm{Fe}^{2+}}$ and $m_{\mathrm{H}^{+}}$denote the stoichiometric coefficients for eqs 4 to 6. $E_{\mathrm{H}}^{0}[\mathrm{~V}]$ is the standard reduction potential of the iron oxide $\left(E_{\mathrm{H}}^{0}=+0.985 \mathrm{~V},^{60}+0.768 \mathrm{~V}^{61}\right.$ and $+0.769 \mathrm{~V}^{61}$ for ferrihydrite, goethite, and hematite, respectively). $\left\{\mathrm{Fe}_{\mathrm{aq}}^{2+}\right\}\left[\mathrm{mol} \mathrm{L}{ }^{-1}\right]$ is the activity of aqueous ferrous iron calculated using the Davies equation (SI eq S3 in Section S9.1). A detailed description of the $\Delta_{\mathrm{r}} G$ calculations is provided in SI Section S9.1.

According to eqs 7 and 8 , the $\Delta_{\mathrm{r}} G$ of the iron oxide reduction linearly depends on the logarithm of the dissolved ferrous iron activity (recently also shown experimentally in Gorski et al. $\left.{ }^{61}\right)$. Because $\left\{\mathrm{Fe}_{\mathrm{aq}}^{2+}\right\}$ increases during an MER experiment, calculations of $\Delta_{\mathrm{r}} G$ for reaction eqs 4 to 6 require explicit assumptions for $\left\{\mathrm{Fe}_{\mathrm{aq}}^{2+}\right\}$. We calculated $\Delta_{\mathrm{r}} G$ for two selected $\left\{\mathrm{Fe}_{\mathrm{aq}}^{2+}\right\}$ that corresponded to two different stages of oxide reduction: (i) the time of the maximum rate of electron 

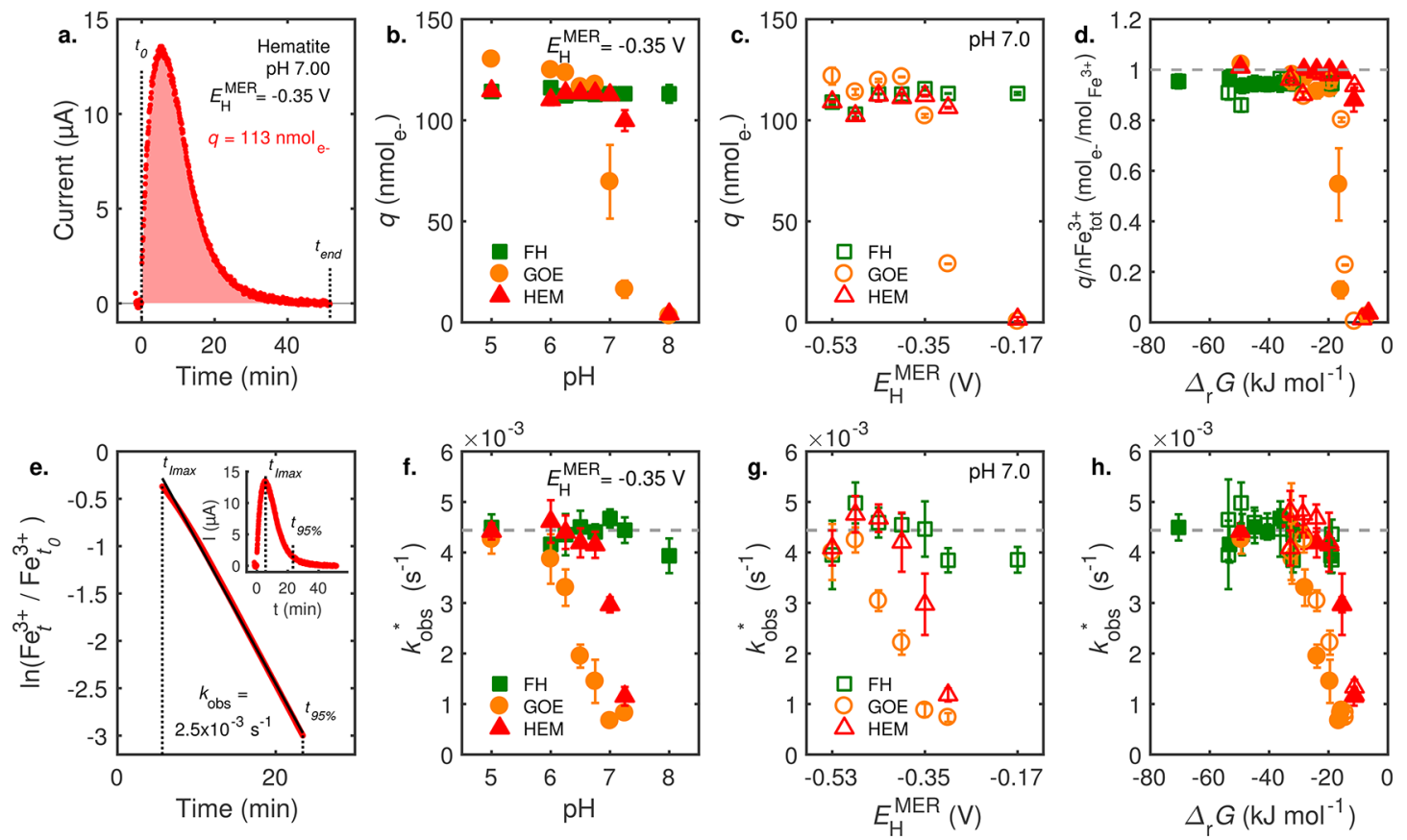

Figure 2. Mediated electrochemical reduction of ferrihydrite $(\mathrm{FH})$, goethite $(\mathrm{GOE})$ and hematite $(\mathrm{HEM})$ at $\mathrm{pH} 5.0-8.0\left(E_{\mathrm{H}}^{\mathrm{MER}}=-0.35 \mathrm{~V}\right)$ and at $E_{\mathrm{H}}^{\mathrm{MER}}=-0.53$ to $-0.17 \mathrm{~V}(\mathrm{pH} 7.0)$. a. Illustrative example for the determination of the number of electrons transferred, $q$, from current responses by peak integration according to eq $1 . q$ values for $\mathrm{FH}, \mathrm{GOE}$ and HEM reduction are shown versus $\mathrm{pH}$ (b.) and $E_{\mathrm{H}}^{\mathrm{MER}}$ (c.). d. The fraction of $q$ relative to the total number of iron atoms, $\mathrm{nFe}_{\mathrm{tot}}^{3+}\left(\mathrm{mol}_{\mathrm{e}}^{-} / \mathrm{mol}_{\mathrm{Fe}^{3+}}\right)$, shown versus $\Delta_{\mathrm{r}} \mathrm{G} . \Delta_{\mathrm{r}} \mathrm{G}$ values were calculated using eq 7 with the $\mathrm{Fe}^{2+}$ activity that resulted from complete reduction of the added oxide (see SI Section S9.1 for details). e. Illustrative example for the determination of observed reduction rate constants, $k_{\mathrm{obs}}$, from peaks in current responses according to eq 2 between the time of the maximum current, $t_{\mathrm{Imax}}$ and the time at which $95 \%$ of the oxide was reduced, $t_{95 \%}$. $k_{\mathrm{obs}}$ values were corrected $\left(k_{\mathrm{obs}}^{*}\right)$ based on eq 3 and are shown versus $\mathrm{pH}(\mathrm{f}),. E_{\mathrm{H}}^{\mathrm{MER}}\left(\mathrm{g}\right.$.) and $\Delta_{\mathrm{r}} G(\mathrm{~h}$.). The dashed gray lines in panels $\mathrm{f} .-\mathrm{h}$. depict the average mediator $k_{\mathrm{obs}}$ over all experiments (see Materials and Methods for details). Filled and empty markers in panels d. and h. refer to data obtained at varying $\mathrm{pH}$ and constant $E_{\mathrm{H}}^{\mathrm{MER}}$ and at varying $E_{\mathrm{H}}^{\mathrm{MER}}$ and constant $\mathrm{pH}$, respectively.

transfer across the WE (i.e., $\left\{\mathrm{Fe}_{\mathrm{aq}}^{2+}\right\}$ was calculated based on eq 1 with integration boundaries from $t_{0}$ to $t_{I \max }$ ), and (ii) the end of the reduction reaction (i.e., $\left\{\mathrm{Fe}_{\mathrm{aq}}^{2+}\right\}$ was calculated based on eq 1 by integration of the entire reductive current peak). SI Section $S 9$ provides more details on the calculation of $\Delta_{\mathrm{r}} G$ for the two different stages of iron oxide reduction.

\section{RESULTS AND DISCUSSION}

Qualitative Analysis of Iron Oxide Reduction. We determined the reductive current responses of iron oxides in MER over a range of solution $\mathrm{pH}$ in the electrochemical cell (i.e., from $\mathrm{pH} 5.0$ to 8.0 at $E_{\mathrm{H}}^{\mathrm{MER}}=-0.35 \mathrm{~V}$ ) and at different $E_{\mathrm{H}}^{\mathrm{MER}}$ (i.e., from $E_{\mathrm{H}}^{\mathrm{MER}}=-0.53$ to $-0.17 \mathrm{~V}$ at $\mathrm{pH} 7.0$ ). The MER conditions are depicted as black stars in Figure 1a, d, and $\mathrm{g}$ for ferrihydrite, goethite, and hematite, respectively. The filled areas in the upper right corners of panels a, d, and g depict the $E_{\mathrm{H}}-\mathrm{pH}$ conditions under which the iron oxides are thermodynamically stable (i.e., $\Delta_{\mathrm{r}} G \geq 0$ with a ferrous iron concentration of $1 \mu \mathrm{M})$. The gray lines parallel to the iron oxide stability lines connect $E_{\mathrm{H}}-\mathrm{pH}$ conditions with the same $\Delta_{\mathrm{r}} G$ values for oxide reduction (shown in increments of $-20 \mathrm{~kJ}$ $\mathrm{mol}^{-1}$ ). Reduction of the three oxides was thermodynamically favorable under all experimental conditions. However, the experimental $\mathrm{pH}$ and $E_{\mathrm{H}}^{\mathrm{MER}}$ conditions resulted in less negative $\Delta_{\mathrm{r}} G$ values for goethite and hematite than ferrihydrite reduction due to the higher $E_{\mathrm{H}}^{0}$ of ferrihydrite.

The remaining panels of Figure 1 show selected reductive current responses to additions of the three iron oxides to electrochemical cells run at different $\mathrm{pH}$ and $E_{\mathrm{H}}^{\mathrm{MER}}$. For ferrihydrite, increasing the solution $\mathrm{pH}$ from 5.0 to 8.0 resulted in decreasing heights (and hence $I_{\max }$ values) and increasing widths of the reductive current peaks, meaning reduction rates decreased (Figure 1b). Similar to the effect of $\mathrm{pH}$, the heights of the reductive current peaks for ferrihydrite decreased and the widths of the peaks increased with increasing $E_{\mathrm{H}}^{\mathrm{MER}}$ from -0.53 $\mathrm{V}$ to $-0.17 \mathrm{~V}$ (Figure 1c). Compared to ferrihydrite, increasing $\mathrm{pH}$ and $E_{\mathrm{H}}^{\mathrm{MER}}$ had much stronger effects on the shapes of the reductive current peaks for goethite (panels e and f) and hematite (panels $\mathrm{h}$ and $\mathrm{i}$ ). For these two iron oxides, the reductive current peaks were very small and broad at $\mathrm{pH}$ values $\geq 7.0$ and $E_{\mathrm{H}}^{\mathrm{MER}} \geq-0.35 \mathrm{~V}$. Overall, the observed changes in the reductive current responses with $\mathrm{pH}$ and $E_{\mathrm{H}}^{\mathrm{MER}}$ demonstrated that the reactivity of the three iron oxides decreased with increasing $\Delta_{\mathrm{r}} G$ to less negative values and thus decreasing thermodynamic driving force for iron oxide reduction.

Quantitative Analysis of the Effects of $\mathrm{pH}$ and $E_{\mathrm{H}}^{\mathrm{MER}}$ on Iron Oxide Reduction. Extents of Iron Oxide Reduction. We determined the extents of iron oxide reduction by quantifying the number of electrons transferred to the iron oxides, $q$ (eq 1 ). As an illustrative example, Figure 2 a depicts a selected reductive current peak resulting from the addition of $50 \mu \mathrm{L}$ of a hematite suspension to a MER cell run at $\mathrm{pH} 7.00$ and $E_{\mathrm{H}}^{\mathrm{MER}}=-0.35 \mathrm{~V}$. Integration of this peak showed that $q=113 \mathrm{nmol}_{\mathrm{e}-}$ were transferred from the WE to hematite. The high signal-to-noise ratio of the current response and the small number of electrons transferred emphasize the high sensitivity of MER.

While increasing $\mathrm{pH}$ and $E_{\mathrm{H}}^{\mathrm{MER}}$ decreased the heights of the reductive current peaks of ferrihydrite (Figure $1 \mathrm{~b}, \mathrm{c}$ ), integration of these peaks showed that approximately the same number of electrons were transferred to ferrihydrite under 
all tested conditions (green squares in Figure $2 \mathrm{~b}, \mathrm{c}$ ). Goethite and hematite reduction at $\mathrm{pH}<7.0\left(E_{\mathrm{H}}^{\mathrm{MER}}=-0.35 \mathrm{~V}\right)$ and $E_{\mathrm{H}}^{\mathrm{MER}}<-0.35 \mathrm{~V}(\mathrm{pH} 7.0)$ also showed comparable and constant $q$ values. However, reduction of these two iron oxides at higher $\mathrm{pH}$ and $E_{\mathrm{H}}^{\mathrm{MER}}$ resulted in decreasing $q$ values with increasing $\mathrm{pH}$ and $E_{\mathrm{H}}^{\mathrm{MER}}$ (orange circles and red triangles in Figure $2 b, c)$. The extents of goethite and hematite reduction thus decreased as their reduction became thermodynamically less favorable. To compare the extents of reduction under different experimental conditions and among the three iron oxides, we normalized $q$ to the total amount of iron that was transferred into the electrochemical cell in a given oxide addition, $\mathrm{nFe}_{\text {tot }}^{3+}$. Furthermore, we converted the different $\mathrm{pH}$ and $E_{\mathrm{H}}^{\mathrm{MER}}$ conditions to $\Delta_{\mathrm{r}} G$ values using eqs 7 and 8 . As detailed in the Materials and Methods and SI Section S9, we calculated $\Delta_{\mathrm{r}} G$ values for two ferrous iron activities, $\left\{\mathrm{Fe}_{\mathrm{aq}}^{2+}\right\}$. Figure $2 \mathrm{~d}$ shows the ratios of $q / \mathrm{nFe}_{\text {tot }}^{3+}$ plotted versus $\Delta_{\mathrm{r}} G$ values that we calculated for $\left\{\mathrm{Fe}_{\mathrm{aq}}^{2+}\right\}$ at the end of the iron oxide reduction. The trends described below were also observed for the other $\left\{\mathrm{Fe}_{\mathrm{aq}}^{2+}\right\}$ scenario which merely shifted $\Delta_{\mathrm{r}} G$ to slightly more negative values (SI Section S9.2).

For ferrihydrite, the number of electrons transferred was in good agreement with the amount of $\mathrm{Fe}^{3+}$ added at all tested $\mathrm{pH}$ and $E_{\mathrm{H}}^{\mathrm{MER}}$ (i.e., $q / \mathrm{nFe}_{\text {tot }}^{3+}=1$, Figure $2 \mathrm{~d}$ ), suggesting that reduction thermodynamics for ferrihydrite were sufficiently favorable under all conditions to result in complete reduction of the added ferrihydrite $\mathrm{Fe}^{3+}$ to $\mathrm{Fe}^{2+}$. Fast and complete reduction of ferrihydrite likely ruled out its recrystallization to thermodynamically more stable phases during MER. Conversely, goethite and hematite were completely reduced (i.e., q/ $\left.\mathrm{nFe}_{\text {tot }}^{3+}=1\right)$ only at $\Delta_{\mathrm{r}} G$ values more negative than $\approx-20$ and $\approx-15 \mathrm{~kJ} \mathrm{~mol}^{-1}$, respectively. At less negative $\Delta_{\mathrm{r}} G$ values, the reduction of goethite and hematite started to be incomplete (i.e., $q / \mathrm{nFe}_{\text {tot }}^{3+}<1$ ). At the least negative $\Delta_{\mathrm{r}} G$ values of $\approx-5 \mathrm{~kJ}$ $\mathrm{mol}^{-1}$, the $q / \mathrm{nFe}_{\text {tot }}^{3+}$ ratios of goethite and hematite approached zero. We ascribe incomplete goethite and hematite reduction under these conditions to (net) electron transfer rates to the oxides that were too small to be accessible to the MER setup (i.e., reductive current responses were too small to be detected relative to the baseline current). It is possible that increasing reversibility of electron transfer to the oxide (i.e., increase in electron transfer from $\mathrm{Fe}^{2+}$ formed on the oxide surface back to oxidized mediator molecules in solution) contributed to overall slow iron oxide reduction at high $E_{\mathrm{H}}^{\mathrm{MER}}$ and $\mathrm{pH}$. We consider it less likely that the incomplete reduction resulted from transformation of goethite and hematite to more stable phases, because such transformations typically occur on longer time scales. ${ }^{62-64}$ At the same time, the observed strong dependence of the reduction extents of goethite and hematite on $\Delta_{\mathrm{r}} G$ values shows that MER can be used to characterize iron oxide reducibility as a function of reduction thermodynamics (Figure $2 \mathrm{~d}$ ). In fact, the good agreement in the extents of reduction between the two data sets collected at different $\mathrm{pH}$ (closed symbols, Figure $2 \mathrm{~b}$ ) and at different $E_{\mathrm{H}}^{\mathrm{MER}}$ (open symbols, Figure 2c) suggests that system thermodynamics controlled the extents of goethite and hematite reduction (see SI Section S10 for current responses obtained at the same $\Delta_{\mathrm{r}} G$ but different $E_{\mathrm{H}}^{\mathrm{MER}}-\mathrm{pH}$ conditions). The agreement between the two data sets is particularly evident for goethite for which the extents of reduction decreased over a very narrow $\Delta_{\mathrm{r}} G$ range, irrespective of whether the reduction driving force was altered by varying the $\mathrm{pH}$ or $E_{\mathrm{H}}^{\mathrm{MER}}$.
Rates of Iron Oxide Reduction. Past studies using mediated electrochemical analysis almost exclusively utilized the measured current responses to quantify the number of electrons transferred to and from geochemical phases. This work is the first to systematically assess the possibility to derive rates of electron transfer from the reductive current peaks measured in MER. To this end, we determined observed rate constants, $k_{\text {obs, }}$ for iron oxide reduction for all experiments that resulted in complete oxide reduction (i.e., $q / \mathrm{nFe}_{\text {tot }}^{3+} \approx 1$ ). We assume that complete reductive dissolution rules out phase transformation of the iron oxides during MER. The data treatment to obtain $k_{\text {obs }}$ values is illustrated in Figure 2e using the same exemplary current peak as in Figure 2a (i.e., hematite reduction at $\mathrm{pH} 7.00$ and $\left.E_{\mathrm{H}}^{\mathrm{MER}}=-0.35 \mathrm{~V}\right)$. In a first step, we stepwise integrated the reductive current peak to determine the fractions of added ferric iron that remained in the electrochemical cell at any given time $t$ (i.e., $\left.\mathrm{Fe}_{t}^{3+} / \mathrm{Fe}_{t_{0}}^{3+}\right)$. In a second step, we plotted the natural logarithm of $\mathrm{Fe}_{t}^{3+} / \mathrm{Fe}_{t_{0}}^{3+}$ versus time $t$ (Figure 2e). We restricted our analysis to data collected between the time at which the reductive current peaked (i.e., $t_{\operatorname{Imax}}$ ) and the time at which $95 \%$ of the added oxide were reduced, $t_{95 \%}$. The converted current data was accurately fitted by eq 2 (Figure $2 \mathrm{e}$ ), yielding a $k_{\text {obs }}$ value for hematite reduction of $2.5 \cdot 10^{-3} \mathrm{~s}^{-1}$ under the given conditions. The finding that a single $k_{\mathrm{obs}}$ value accurately described the converted current data could be ascribed to the constant $\mathrm{pH}, E_{\mathrm{H}}^{\mathrm{MER}}$, and reduced mediator concentration during MER. Fits of comparable quality and very similar $k_{\text {obs }}$ values were obtained when fitting the current data using the general rate law for mineral dissolution proposed by Christoffersen and Christoffersen $^{58}$ and Postma ${ }^{59}$ (see SI Section S8) instead of eq 2. The following discussion is based on rate data obtained using eq 2 .

We note that neither of the two rate models predict the observed increase in reductive currents during the initial phase of iron oxide reduction from $t_{0}$ to $t_{\text {Imax }}$ which was more pronounced for goethite and hematite than for ferrihydrite (Figure 1). Conversely, such a gradual increase was not seen for the mediator addition after which $I_{\max }$ was reached within $<20$ s (see SI Section S4). The gradual initial current increases to a maximum suggested an initial increase in iron oxide reducibility following their addition to the MER cells. The underlying cause of this observation remains unidentified. The current increase was too gradual to have resulted from the re-reduction of oxidized mediator species in the cell that had formed by electron transfer from reduced mediator to the iron oxide (i.e., the addition of oxidized mediator to the MER cell resulted in very sharp current increases to $I_{\max }$ ). A possible explanation for the gradual initial increase in reductive currents is that $\mathrm{Fe}^{2+}$ formed upon initial oxide reduction facilitated disaggregation of the added oxides, thereby increasing the surface area readily available to the reduced mediator for electron transfer. This explanation is supported by the finding that between $20 \%$ and $30 \%$ of the ferric iron added as goethite and hematite had been reduced when $I_{\max }$ was reached (SI Section S6). Such $\mathrm{Fe}^{2+}$ induced disaggregation was recently proposed for goethite and ferrihydrite. $^{63,66}$

Figure $2 \mathrm{f}$ and $\mathrm{g}$ show $k_{\mathrm{obs}}^{*}$ values for all three oxides obtained from experiments in which we varied $\mathrm{pH}$ at constant $E_{\mathrm{H}}^{\mathrm{MER}}$ (panel f) and $E_{\mathrm{H}}^{\mathrm{MER}}$ at constant $\mathrm{pH}$ (panel g). The dashed horizontal lines correspond to $k_{\mathrm{obs}}^{\mathrm{med}}$ av averaged over all mediator measurements $\left(k_{\mathrm{obs}, \text { av }}^{\mathrm{med}}=4.44 \pm 0.63 \cdot 10^{-3} \mathrm{~s}^{-1}\right)$. Ferrihydrite reduction at all $\mathrm{pH}$ and $E_{\mathrm{H}}^{\mathrm{MER}}$ resulted in $k_{\mathrm{obs}}^{*}$ that scattered 

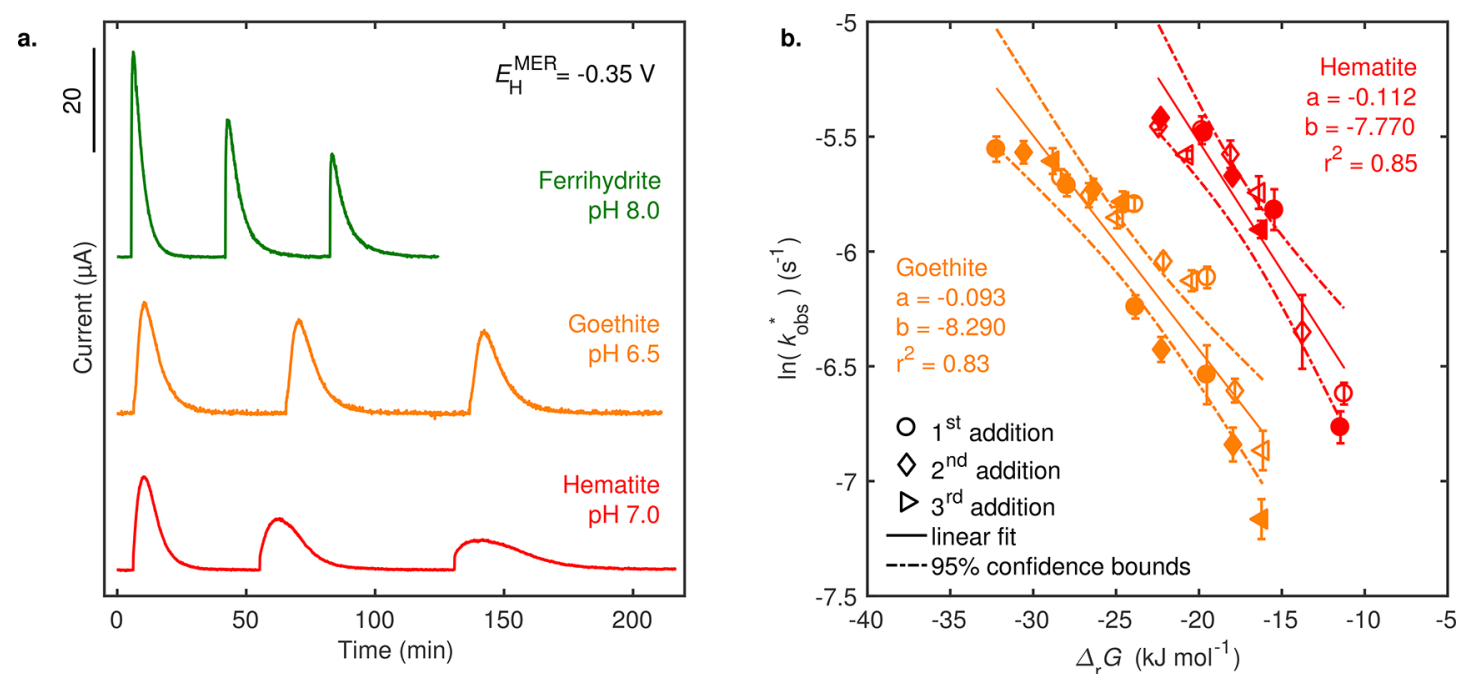

Figure 3. Effect of ferrous iron on electron transfer to ferrihydrite, goethite and hematite. a. Exemplary reductive current responses to three consecutive additions of ferrihydrite, goethite and hematite to electrochemical cells $\left(E_{\mathrm{H}}^{\mathrm{MER}}=-0.35 \mathrm{~V}\right)$. b. Observed corrected reduction rate constants, $k_{\mathrm{obs}}^{*}$, of goethite and hematite reduction as a function of $\Delta_{\mathrm{r}} G$. $k_{\mathrm{obs}}^{*}$ values were determined using eqs 2 and 3 and $\Delta_{\mathrm{r}} G$ values were calculated using eq 7 with ferrous iron concentrations that resulted from complete reduction of the added oxide (see SI Section S9.1 for details). Closed symbols represent experiments run at varying $\mathrm{pH}$ and open symbols represent experiments run at varying $E_{\mathrm{H}}^{\mathrm{MER}}$. Data were fitted separately for goethite and hematite using the linear equation $\ln \left(k_{\mathrm{obs}}^{*}\right)=\mathrm{a} \cdot \Delta_{\mathrm{r}} G+\mathrm{b}$.

around $k_{\mathrm{obs} \text {, av }}^{\mathrm{med}}$ values. This finding implies that the rate of electron transfer from the reduced mediator to ferrihydrite was at least as high as the rate at which the formed oxidized mediator species were re-reduced at the WE. The rates of mediator re-reduction thus kinetically masked the rates of electron transfer from the reduced mediator to ferrihydrite. While the rates of mediator re-reduction also masked rates of goethite and hematite reduction at the lower tested $\mathrm{pH}$ and $E_{\mathrm{H}}^{\mathrm{MER}}$ (Figure 2f and $\mathrm{g}$ ), experiments run at $\mathrm{pH} 6.00$ to 6.75 $\left(E_{\mathrm{H}}^{\mathrm{MER}}=-0.35 \mathrm{~V}\right)$ and $E_{\mathrm{H}}^{\mathrm{MER}}=-0.395$ to $-0.485 \mathrm{~V}(\mathrm{pH} 7.0)$ for goethite and at $\mathrm{pH} 6.75$ to $7.25\left(E_{\mathrm{H}}^{\mathrm{MER}}=-0.35 \mathrm{~V}\right)$ and $E_{\mathrm{H}}^{\mathrm{MER}}$ $=-0.305$ to $-0.395(\mathrm{pH} 7.0)$ for hematite resulted in $k_{\mathrm{obs}}^{*}$ smaller than the average $k_{\mathrm{obs}}^{\mathrm{med}}$. Under these conditions, the measured currents were thus controlled by the rates of electron transfer from the reduced mediator to the iron oxides.

To directly compare the effects of $\mathrm{pH}$ and $E_{\mathrm{H}}^{\mathrm{MER}}$ on goethite and hematite reduction rates, we replotted $k_{\mathrm{obs}}^{*}$ values versus the corresponding $\Delta_{\mathrm{r}} G$ values in Figure $2 \mathrm{~h}$. We used the $\mathrm{Fe}^{2+}$ activity that resulted from complete reduction of the added iron oxide to calculate $\Delta_{\mathrm{r}} G$ values. A comparison of panels $\mathrm{h}$ and $\mathrm{d}$ in Figure 2 shows that the rate constants of goethite and hematite reduction were much more sensitive to changes in reduction thermodynamics than the extents of electron transfer to these oxides: compared to $q$ values, the $k_{\mathrm{obs}}^{*}$ values for goethite and hematite started to decrease at lower $\Delta_{\mathrm{r}} G$ values and over wider $\Delta_{\mathrm{r}} G$ ranges. For each of the iron oxides, plotting $k_{\mathrm{obs}}^{*}$ versus $\Delta_{\mathrm{r}} G$ (Figure $2 \mathrm{~h}$ ) resulted in good agreement between the data sets obtained at different $\mathrm{pH}$ (closed symbols) and $E_{\mathrm{H}}^{\mathrm{MER}}$ (open symbols), similar to the agreement for the extents of reduction discussed above (Figure 2d). This finding suggests that reduction thermodynamics controlled the rates of goethite and hematite reduction.

Quantitative Analysis of the Effects of $\mathrm{Fe}^{2+}$ on Iron Oxide Reduction Rate Constants. The $\Delta_{\mathrm{r}} G$ for iron oxide reduction increased to less negative values as $\mathrm{Fe}^{2+}$ activities increased according to eqs 7 and 8 . In addition to varying $\mathrm{pH}$ and $E_{\mathrm{H}}^{\mathrm{MER}}$, we therefore also assessed the effects of increasing $\mathrm{Fe}^{2+}$ activities in the electrochemical cells on iron oxide reduction rates. To this end, we compared the current peaks that resulted from the first iron oxide addition, discussed in detail above in Figure 2, to the current peaks that resulted from a second and a third oxide addition to the same electrochemical cell. While the same amount of iron oxide was transferred in all three consecutive additions, the $\mathrm{Fe}^{2+}$ activity in the cell increased from the first to the second and third additions as a result of reductive iron oxide dissolution. We carried out the three sequential iron oxide additions at all $\mathrm{pH}$ and $E_{\mathrm{H}}^{\mathrm{MER}}$ conditions illustrated in Figure 1 but limit our discussion to selected experiments (see SI Section S11 for additional experiments). For goethite and hematite, we discuss data that was collected over the $\Delta_{\mathrm{r}} G$ range in which reduction was complete but $k_{\mathrm{obs}}^{*}$ values decreased (Figure $2 \mathrm{~h}, \Delta_{\mathrm{r}} G$ from -28 to $-19 \mathrm{~kJ} \mathrm{~mol}^{-1}$ for goethite and from -20 to $-11 \mathrm{~kJ} \mathrm{~mol}^{-1}$ for hematite). At more negative $\Delta_{\mathrm{r}} G$ values, the three current peaks had very similar shapes, implying that increasing $\mathrm{Fe}^{2+}$ activities had no observable effect on the extents and rates of oxide reduction (SI Section S11). Conversely, once $\Delta_{\mathrm{r}} G$ values approached $-10 \mathrm{~kJ} \mathrm{~mol}^{-1}$, reduction was incomplete and the reductive current peaks were too small to be analyzed (SI Section S11).

Figure $3 \mathrm{a}$ shows selected current responses to three sequential additions of ferrihydrite $(\mathrm{pH} 8.0)$, goethite $(\mathrm{pH}$ $6.5)$, and hematite $(\mathrm{pH} 7.0)$, all at $E_{\mathrm{H}}^{\mathrm{MER}}=-0.35 \mathrm{~V}$. For all three oxides, the peak heights decreased and the peak widths increased with increasing activities of $\mathrm{Fe}^{2+}$. Analysis of the current peaks showed that $q$ values decreased only slightly from the first to the second and third addition, while the decrease in $k_{\mathrm{obs}}^{*}$ was much more pronounced. The buildup of $\mathrm{Fe}^{2+}$ in the cells thus slowed down iron oxide reduction.

We confirmed that decreasing rates of iron oxide reduction resulted from increasing $\mathrm{Fe}^{2+}$ activities in two sets of control experiments run for goethite $\left(\mathrm{pH} 6.5, E_{\mathrm{H}}^{\mathrm{MER}}=-0.35 \mathrm{~V}\right)$ and hematite $\left(\mathrm{pH} \mathrm{7.0,} E_{\mathrm{H}}^{\mathrm{MER}}=-0.35 \mathrm{~V}\right)$. In the first control, we added dissolved $\mathrm{Fe}^{2+}$ to the electrochemical cells once prior to the three consecutive iron oxide additions. The amount of added $\mathrm{Fe}^{2+}$ was identical to the amount of $\mathrm{Fe}^{2+}$ that formed 

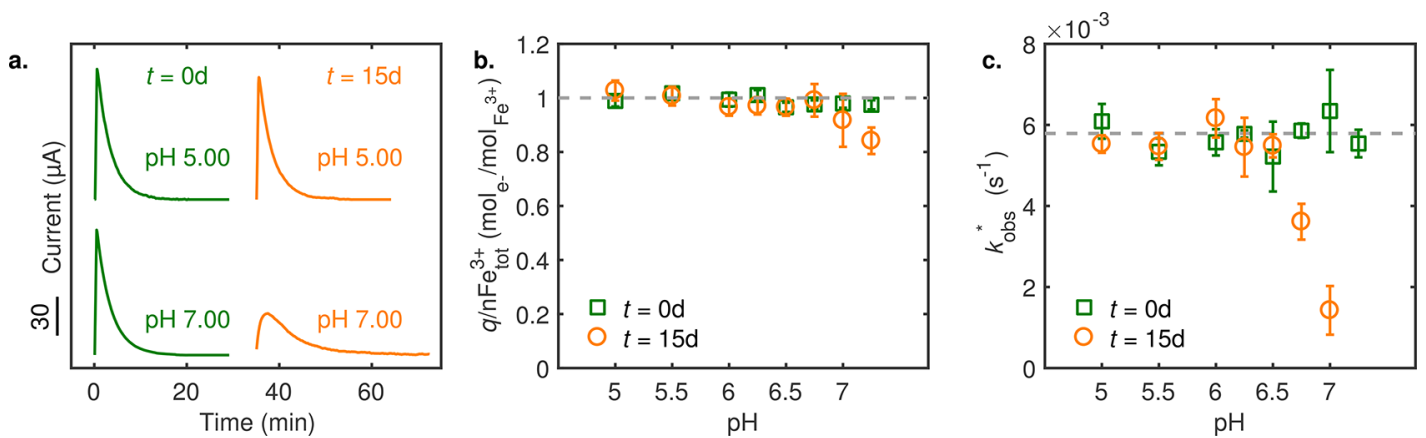

Figure 4. Changes in iron oxide reactivity during transformation of ferrihydrite $\left(10 \mathrm{mM} \mathrm{Fe}^{3+}\right)$ to goethite in the presence of $1 \mathrm{mM} \mathrm{Fe} \mathrm{m}^{2+}$ at $\mathrm{pH} 7.0$. MER experiments were performed at $\mathrm{pH} 5.00$ to 7.25 and $E_{\mathrm{H}}^{\mathrm{MER}}=-0.35 \mathrm{~V}$ on aliquots removed from duplicate batch reactors at the beginning $(t=0$ d) and at the end $(t=15 \mathrm{~d})$ of the transformation. a. Exemplary current responses obtained at $\mathrm{pH} 5.00$ and 7.00 at $t=0 \mathrm{~d}$ and $t=15 \mathrm{~d}$. b. Relative reduction extents, $q / \mathrm{nFe} e_{\text {tot }}^{3+}$ and c. observed corrected reduction rate constants, $k_{\mathrm{obs}}^{*}$ (determined using eqs 2 and 3 ) at $t=0 \mathrm{~d}$ and $t=15 \mathrm{~d}$ shown versus the $\mathrm{pH}$ in the MER measurement.

during the complete reduction of $\mathrm{Fe}^{3+}$ in one of the three iron oxide additions. Prior addition of $\mathrm{Fe}^{2+}$ to the MER cells decreased the heights and increased the widths of the current peaks in all three subsequent oxide additions as shown in SI Figures $\mathrm{S} 14$ and S15, confirming it was $\mathrm{Fe}^{2+}$ that decreased goethite and hematite reduction rates. In the second set of control experiments, we added phenanthroline, a strong complexing agent for $\mathrm{Fe}^{2+}$, prior to each of the three goethite and hematite additions. Phenanthroline was always added in a 3:1 molar ratio compared to the amount of $\mathrm{Fe}^{3+}$ in the subsequent oxide addition. This molar ratio corresponds to the stoichiometry of the phenanthroline- $\mathrm{Fe}^{2+}$ complex. ${ }^{67}$ SI Figures S14 and S15 show that the complexation of $\mathrm{Fe}_{\mathrm{aq}}^{2+}$ by phenanthroline increased the height and decreased the widths of all three reductive current peaks of goethite and hematite.

Linking Rate Constants to Free Energies of Iron Oxide Reduction. We assessed whether the effect of accumulating $\mathrm{Fe}^{2+}$ on the reduction rate constants of goethite and hematite can be linked to changes in reduction thermodynamics, similar to the effects of $\mathrm{pH}$ and $E_{\mathrm{H}}^{\mathrm{MER}}$. To this end, we replotted rate constants from all three iron oxide additions and all $\mathrm{pH}$ and $E_{\mathrm{H}}^{\mathrm{MER}}$ conditions as the natural logarithm of $k_{\mathrm{obs}}^{*}$ versus calculated $\Delta_{\mathrm{r}} G$ values. Such linear free energy relations are a widely used concept to relate kinetic information to the thermodynamic descriptors of a chemical reaction. ${ }^{68,69}$ We use such a relation here to infer the impact of changes in $\Delta_{\mathrm{r}} G$ on the rate-limiting step of the reductive iron oxide dissolution. Note that the data shown in Figure $3 \mathrm{~b}$ is restricted to reduction rate constants from experiments that resulted in complete oxide reduction with $k_{\mathrm{obs}}^{*}<k_{\mathrm{obs} \text {, av }}^{\mathrm{med}}$ The $\Delta_{\mathrm{r}} G$ values for the second and third oxide additions were calculated using the cumulative $\mathrm{Fe}^{2+}$ activities in the electrochemical cells at the end of these additions (i.e., including the $\mathrm{Fe}^{2+}$ formed in preceding oxide reduction steps).

Figure $3 \mathrm{~b}$ shows that $\ln \left(k_{\mathrm{obs}}^{*}\right)$ values obtained from all three consecutive oxide additions were linearly correlated with the respective $\Delta_{\mathrm{r}} G$ values. We note that rates of mediator rereduction may have slightly masked the higher $k_{\mathrm{obs}}^{*}$ values in this correlation. More importantly, the good agreement of the rate constants from different experiments in which we varied $\mathrm{pH}, E_{\mathrm{H}}^{\mathrm{MER}}$, and $\mathrm{Fe}^{2+}$ implies that $\Delta_{\mathrm{r}} G$ controlled the kinetics of goethite and hematite reduction under the conditions studied in the MER system. We note that these conditions (i.e., the presence of a one-electron transfer mediator and highly negative free energies for iron oxide reduction) were different from those typically encountered in natural systems containing iron oxides. As a consequence, our results may not be directly applicable to natural systems. Our work calls for future studies that specifically assess the degree to which thermodynamics control iron oxide reduction rates also in natural systems with different reductants and less negative $\Delta_{\mathrm{r}} G$ than tested herein.

As established previously, the reductive dissolution of iron oxides is a four step process which includes (i) precursor complex formation of the iron on the oxide surface and the chemical reductant, (ii) electron transfer from the reductant to the iron, (iii) release of the oxidized mediator species, and (iv) oxide surface protonation, release of reduced $\mathrm{Fe}^{2+}$ and reexposure of ferric iron on the oxide surface. ${ }^{70}$ In pulse radiolysis experiments, Mulvaney et al. ${ }^{55}$ showed that that steps (i) to (iii) for iron oxides and reduced viologens, which were similar to the ones used here, are much faster than step (iv). This interpretation is consistent with other studies that have identified step (iv) to govern overall reduction rates. ${ }^{55,71-73}$ Within this step, protonation equilibria between the iron oxide surface and solution protons are considered to be rapid, whereas the release of the formed $\mathrm{Fe}^{2+}$ is slow. ${ }^{55}$ For these reasons, we propose that for experiments shown in Figure $3 \mathrm{~b}$ the desorption of $\mathrm{Fe}^{2+}$ from the iron oxide surfaces controlled the overall rate of iron oxide reduction in the electrochemical cells: the rate of $\mathrm{Fe}^{2+}$ desorption from the iron oxide surface determined the rate at which ferric iron became exposed on the iron oxide surface and, thereby, the rate at which electrons were transferred from reduced mediator molecules to the iron oxide surface. The trends shown in Figure $3 \mathrm{~b}$ are consistent with this mechanism in that the release of $\mathrm{Fe}^{2+}$ increased the activity of $\mathrm{Fe}^{2+}$ in solution and thereby lowered the $E_{\mathrm{H}}^{\text {oxide }}$ according to eq 8.

For any given $\Delta_{\mathrm{r}} G$ in Figure $3 \mathrm{~b}, k_{\mathrm{obs}}^{*}$ values for hematite reduction were higher than for goethite reduction. We note, however, that the rate constants of goethite and hematite reduction should not be directly compared because of differences in specific surface areas, particle properties, morphologies and sizes, and aggregation states. In our case, even after normalization of $k_{\mathrm{obs}}^{*}$ to the specific surface area of goethite $\left(35.8 \mathrm{~m}^{2} \mathrm{~g}^{-1}\right)$ and hematite $\left(46.3 \mathrm{~m}^{2} \mathrm{~g}^{-1}\right)$, hematite was more reactive than goethite (SI Section S12). Therefore, the observed reactivity differences between goethite and hematite may have resulted from differences in their preparation rather than their mineralogies. In fact, literature studies reported slower, comparable and faster reduction rates 
of goethite compared to hematite. ${ }^{70,73-75}$ We note that our rate data for goethite and hematite reduction are in good agreement with reduction rates reported by Shi et al. ${ }^{54}$ who reduced iron oxides with viologens in batch experiments (SI Sections S12 and S13).

Analysis of Changes in Iron Oxide Reducibility in Dynamic Systems. To demonstrate the applicability of MER to characterize changes in iron oxide reducibility during phase transformations, we ran duplicate transformation experiments of ferrihydrite $\left(10 \mathrm{mM} \mathrm{Fe}^{3+}\right)$ to goethite in the presence of $\mathrm{Fe}^{2+}$ $(1 \mathrm{mM})$. Sample aliquots were removed over the course of the transformation reaction and were analyzed by X-ray diffraction (XRD), transmission electron microscopy (TEM) and MER. Here, we limit our discussion to the analysis of the initial $(t=0$ $\mathrm{d}$ of incubation and prior to $\mathrm{Fe}^{2+}$ addition) and final suspensions $\left(t=15 \mathrm{~d}\right.$ of incubation in the presence of $\left.\mathrm{Fe}^{2+}\right)$. XRD and TEM demonstrated near complete conversion of ferrihydrite at $t=0 \mathrm{~d}$ to goethite at $t=15 \mathrm{~d}$ (i.e., formation of 97.5\% goethite and $2.5 \%$ magnetite; see SI Section S5 for spectra and images). MER experiments were performed at $\mathrm{pH}$ 5.00 to 7.25 and $E_{\mathrm{H}}^{\mathrm{MER}}=-0.35 \mathrm{~V}$. Figure $4 \mathrm{a}$ shows two representative reductive current peaks at $\mathrm{pH} 5.00$ and 7.00 resulting from the additions of the initial and final suspensions. As expected, the reduction of ferrihydrite $(t=0 \mathrm{~d})$ resulted in sharp current peaks across the entire tested $\mathrm{pH}$ range (green trace), whereas goethite reduction (orange trace) resulted in sharp peaks only at low $\mathrm{pH}$ (shown for $\mathrm{pH}$ 5.00) but much broader peaks with smaller maximum currents at higher $\mathrm{pH}$ (shown for $\mathrm{pH}$ 7.00). Integration of the reductive current peaks showed complete reduction of ferrihydrite at all tested $\mathrm{pH}$ (i.e., $\left.q / \mathrm{nFe}_{\text {tot }}^{3+}=1\right)$, whereas the reduction of goethite was complete only up to about $\mathrm{pH} 7.00$ but incomplete at the higher $\mathrm{pH}$ of 7.25 (i.e., $q / \mathrm{nFe}_{\text {tot }}^{3+}=0.84$, Figure $4 \mathrm{~b}$ ). Consistent with the above data, $k_{\mathrm{obs}}^{*}$ values for ferrihydrite and goethite reduction at $\mathrm{pH} \leq 6.5$ all lay within the range of mediator reduction rate constants (Figure 4c). Above $\mathrm{pH}$ 6.5, $k_{\mathrm{obs}}^{*}$ values for goethite decreased below the range of mediator reduction rate constants. We note that higher $k_{\mathrm{obs}}^{*}$ of the goethite from ferrihydrite transformation compared to the goethite in Figures 2 and 3 reflects the lower crystallinity, smaller particle size and surface area of the former as evidenced from XRD, TEM, and $\mathrm{N}_{2}$-BET analyses (SI Sections S2 and S5). These results demonstrate that MER can be used to systematically study changes in the reducibility of iron oxides in dynamic systems involving phase transformations of the iron oxides and/or changes in iron oxide surface chemistry.

\section{ASSOCIATED CONTENT}

\section{S Supporting Information}

The Supporting Information is available free of charge on the ACS Publications website at DOI: 10.1021/acs.est.7b04411.

Chemicals used in this study, iron oxide synthesis and characterization, effect of reduced mediator concentration on iron oxide reduction, scheme of MER experiments, details on the ferrihydrite transformation experiment, fractions of ferric iron reduced at $t_{\text {Imax }}$ evaluation of reductive dissolution rates using a general rate law for mineral dissolution, thermodynamic calculations, illustrative MER current responses, effects of ferrous iron and phenanthroline on iron oxide reduction, surface-area normalized reduction rates and comparison to reduction rates reported in the literature (PDF)

\section{AUTHOR INFORMATION}

\section{Corresponding Authors}

*(T.B.H.) E-mail: thomas.hofstetter@eawag.ch.

*(M.S.) E-mail: michael.sander@env.ethz.ch.

ORCID $\odot$

Andreas Voegelin: 0000-0003-2873-8966

Thomas B. Hofstetter: 0000-0003-1906-367X

Michael Sander: 0000-0003-3383-2041

Notes

The authors declare no competing financial interest.

\section{ACKNOWLEDGMENTS}

We thank Numa Pfenninger, Ralf Kaegi, Stefan Mangold, Prachi Joshi, and S. Sarah Cronk for technical and analytical support, Ashley Brown for helpful discussions of the data, Ruben Kretzschmar for his help with X-ray diffraction measurements and data interpretation and the Swiss National Science Foundation (SNF) for financial support (grant no. 200021 149283/1). Christopher Gorski acknowledges funding from the U.S. National Science Foundation Division of Earth Sciences (award GEO-1451593).

\section{REFERENCES}

(1) Raiswell, R.; Canfield, D. E. The iron biogeochemical cycle past and present. Geochem. perspect. 2012, 1, 1-220.

(2) Taylor, K. G.; Konhauser, K. O. Iron in earth surface systems: A major player in chemical and biological processes. Elements 2011, 7, $83-88$.

(3) Cornell, R. M.; Schwertmann, U. The Iron Oxides: Structure, Properties, Reactions, Occurences and Uses, Second ed.; Second, Completely Revised and Extended ed.; Wiley-VCH Verlag: Weinheim, 2003.

(4) Heckman, K.; Welty-Bernard, A.; Vazquez-Ortega, A.; Schwartz, E.; Chorover, J.; Rasmussen, C. The influence of goethite and gibbsite on soluble nutrient dynamics and microbial community composition. Biogeochemistry 2013, 112, 179-195.

(5) Lalonde, K.; Mucci, A.; Ouellet, A.; Gélinas, Y. Preservation of organic matter in sediments promoted by iron. Nature 2012, 483, 198-200.

(6) Frierdich, A. J.; Catalano, J. G. Distribution and speciation of trace elements in iron and manganese oxide cave deposits. Geochim. Cosmochim. Acta 2012, 91, 240-253.

(7) Frierdich, A. J.; Luo, Y.; Catalano, J. G. Trace element cycling through iron oxide minerals during redox-driven dynamic recrystallization. Geology 2011, 39, 1083-1086.

(8) Latta, D. E.; Gorski, C. A.; Scherer, M. M. Influence of $\mathrm{Fe}^{2+}$ catalysed iron oxide recrystallization on metal cycling. Biochem. Soc. Trans. 2012, 40, 1191-1197.

(9) Borch, T.; Kretzschmar, R.; Kappler, A.; Van Cappellen, P.; Ginder-Vogel, M.; Voegelin, A.; Campbell, K. Biogeochemical redox processes and their impact on contaminant dynamics. Environ. Sci. Technol. 2010, 44, 15-23.

(10) Egger, M.; Rasigraf, O.; Sapart, C. J.; Jilbert, T.; Jetten, M. S. M.; Röckmann, T.; van der Veen, C.; Bândă, N.; Kartal, B.; Ettwig, K. F.; Slomp, C. P. Iron-mediated anaerobic oxidation of methane in brackish coastal sediments. Environ. Sci. Technol. 2015, 49, 277-283.

(11) Beal, E. J.; House, C. H.; Orphan, V. J. Manganese- and irondependent marine methane oxidation. Science 2009, 325, 184-187.

(12) Roden, E. E. Microbial iron-redox cycling in subsurface environments. Biochem. Soc. Trans. 2012, 40, 1249-1256.

(13) Konhauser, K. O.; Kappler, A.; Roden, E. E. Iron in microbial metabolisms. Elements 2011, 7, 89-93. 
(14) Roden, E. E. Fe(III) oxide reactivity toward biological versus chemical reduction. Environ. Sci. Technol. 2003, 37, 1319-1324.

(15) Lovley, D. R. Happy together: microbial communities that hook up to swap electrons. ISME J. 2017, 11, 327-336.

(16) Shrestha, P. M.; Rotaru, A.-E. Plugging in or going wireless: Strategies for interspecies electron transfer. Front. Microbiol. 2014, 5, $1-8$.

(17) Kato, S.; Hashimoto, K.; Watanabe, K. Microbial interspecies electron transfer via electric currents through conductive minerals. Proc. Natl. Acad. Sci. U. S. A. 2012, 109, 10042-10046.

(18) Frierdich, A. J.; Catalano, J. G. Controls on Fe(II)-activated trace element release from goethite and hematite. Environ. Sci. Technol. 2012, 46, 1519-1526.

(19) Frierdich, A. J.; Hasenmueller, E. A.; Catalano, J. G. Composition and structure of nanocrystalline $\mathrm{Fe}$ and $\mathrm{Mn}$ oxide cave deposits: Implications for trace element mobility in karst systems. Chem. Geol. 2011, 284, 82-96.

(20) Wang, Y.; Liu, X.-h.; Si, Y.-b.; Wang, R.-f. Release and transformation of arsenic from As-bearing iron minerals by $\mathrm{Fe}$ reducing bacteria. Chem. Eng. J. 2016, 295, 29-38.

(21) Williams, A. G. B.; Scherer, M. M. Kinetics of Cr(VI) reduction by carbonate green rust. Environ. Sci. Technol. 2001, 35, 3488-3494.

(22) White, A. F.; Peterson, M. L. Reduction of aqueous transition metal species on the surfaces of Fe(II)-containing oxides. Geochim. Cosmochim. Acta 1996, 60, 3799-3814.

(23) Yuan, K.; Ilton, E. S.; Antonio, M. R.; Li, Z.; Cook, P. J.; Becker, $\mathrm{U}$. Electrochemical and spectroscopic evidence on the one-electron reduction of $\mathrm{U}(\mathrm{VI})$ to $\mathrm{U}(\mathrm{V})$ on magnetite. Environ. Sci. Technol. 2015, 49, 6206-6213.

(24) Latta, D. E.; Gorski, C. A.; Boyanov, M. I.; O’Loughlin, E. J.; Kemner, K. M.; Scherer, M. M. Influence of Magnetite Stoichiometry on $\mathrm{U}^{V I}$ Reduction. Environ. Sci. Technol. 2012, 46, 778-786.

(25) Gorski, C. A.; Nurmi, J. T.; Tratnyek, P. G.; Hofstetter, T. B.; Scherer, M. M. Redox behavior of magnetite: Implications for contaminant reduction. Environ. Sci. Technol. 2010, 44, 55-60.

(26) Elsner, M.; Schwarzenbach, R. P.; Haderlein, S. B. Reactivity of $\mathrm{Fe}(\mathrm{II})$-bearing minerals toward reductive transformation of organic contaminants. Environ. Sci. Technol. 2004, 38, 799-807.

(27) Gorski, C. A.; Scherer, M. M. Aquatic Redox Chemistry; $\mathrm{Fe}^{2+}$ Sorption at the $\mathrm{Fe}$ Oxide-Water Interface: A Revised Conceptual Framework; American Chemical Society: Washington, DC, 2011; pp 315-343.

(28) Dixit, S.; Hering, J. G. Sorption of $\mathrm{Fe}(\mathrm{II})$ and $\mathrm{As}(\mathrm{III})$ on goethite in single- and dual-sorbate systems. Chem. Geol. 2006, 228, $6-15$.

(29) Jeon, B.-H.; Dempsey, B. A.; Burgos, W. D.; Royer, R. A. Sorption kinetics of $\mathrm{Fe}(\mathrm{II}), \mathrm{Zn}(\mathrm{II}), \mathrm{Co}(\mathrm{II}), \mathrm{Ni}(\mathrm{II}), \mathrm{Cd}(\mathrm{II})$, and $\mathrm{Fe}(\mathrm{II}) /$ $\mathrm{Me}(\mathrm{II})$ onto hematite. Water Res. 2003, 37, 4135-4142.

(30) Pasakarnis, T. S.; McCormick, M. L.; Parkin, G. F.; Thompson, A.; Scherer, M. M. $\mathrm{Fe}_{\mathrm{aq}}{ }_{\mathrm{II}}-\mathrm{Fe}_{\text {oxide }}$ III electron transfer and $\mathrm{Fe}$ exchange: Effect of organic carbon. Environ. Chem. 2011, 12, 52-63.

(31) Rosso, K. M.; Yanina, S. V.; Gorski, C. A.; Larese-Casanova, P.; Scherer, M. M. Connecting observations of hematite $\left(\alpha-\mathrm{Fe}_{2} \mathrm{O}_{3}\right)$ growth catalyzed by Fe(II). Environ. Sci. Technol. 2010, 44, 61-67.

(32) Williams, A. G. B.; Scherer, M. M. Spectroscopic evidence for $\mathrm{Fe}(\mathrm{II})-\mathrm{Fe}(\mathrm{III})$ electron transfer at the iron oxide-water interface. Environ. Sci. Technol. 2004, 38, 4782-4790.

(33) Joshi, P.; Gorski, C. A. Anisotropic morphological changes in goethite during $\mathrm{Fe}^{2+}$-catalyzed recrystallization. Environ. Sci. Technol. 2016, 50, 7315-7324.

(34) Frierdich, A. J.; Helgeson, M.; Liu, C.; Wang, C.; Rosso, K. M.; Scherer, M. M. Iron atom exchange between hematite and aqueous $\mathrm{Fe}(\mathrm{II})$. Environ. Sci. Technol. 2015, 49, 8479-8486.

(35) Frierdich, A. J.; Beard, B. L.; Reddy, T. R.; Scherer, M. M.; Johnson, C. M. Iron isotope fractionation between aqueous $\mathrm{Fe}(\mathrm{II})$ and goethite revisited: New insights based on a multi-direction approach to equilibrium and isotopic exchange rate modification. Geochim. Cosmochim. Acta 2014, 139, 383-398.
(36) Gorski, C. A.; Handler, R. M.; Beard, B. L.; Pasakarnis, T. S.; Johnson, C. M.; Scherer, M. M. Fe atom exchange between aqueous $\mathrm{Fe}^{2+}$ and magnetite. Environ. Sci. Technol. 2012, 46, 12399-12407.

(37) Liu, C.; Zhu, Z.; Li, F.; Liu, T.; Liao, C.; Lee, J.-J.; Shih, K.; Tao, L.; Wu, Y. Fe(II)-induced phase transformation of ferrihydrite: The inhibition effects and stabilization of divalent metal cations. Chem. Geol. 2016, 444, 110-119.

(38) Boland, D. D.; Collins, R. N.; Miller, C. J.; Glover, C. J.; Waite, T. D. Effect of solution and solid-phase conditions on the $\mathrm{Fe}(\mathrm{II})$ accelerated transformation of ferrihydrite to lepidocrocite and goethite. Environ. Sci. Technol. 2014, 48, 5477-5485.

(39) Handler, R. M.; Frierdich, A. J.; Johnson, C. M.; Rosso, K. M.; Beard, B. L.; Wang, C.; Latta, D. E.; Neumann, A.; Pasakarnis, T. S.; Premaratne, W. A. P. J.; Scherer, M. M. Fe(II)-catalyzed recrystallization of goethite revisited. Environ. Sci. Technol. 2014, 48, 11302-11311.

(40) Boland, D. D.; Collins, R. N.; Glover, C. J.; David Waite, T. An in situ quick-EXAFS and redox potential study of the Fe(II)-catalysed transformation of ferrihydrite. Colloids Surf., A 2013, 435, 2-8.

(41) Kluepfel, L. E.; Piepenbrock, A.; Kappler, A.; Sander, M. Humic substances as fully regenerable electron acceptors in recurrently anoxic environments. Nat. Geosci. 2014, 7, 195-200.

(42) Aeschbacher, M.; Graf, C.; Schwarzenbach, R. P.; Sander, M. Antioxidant properties of humic substances. Environ. Sci. Technol. 2012, 46, 4916-4925.

(43) Kluepfel, L. E.; Keiluweit, M.; Kleber, M.; Sander, M. Redox properties of plant biomass-derived black carbon (biochar). Environ. Sci. Technol. 2014, 48, 5601-5611.

(44) Gorski, C. A.; Kluepfel, L. E.; Voegelin, A.; Sander, M.; Hofstetter, T. B. Redox properties of structural Fe in clay minerals: 3 . Relationships between smectite redox and structural properties. Environ. Sci. Technol. 2013, 47, 13477-13485.

(45) Gorski, C. A.; Kluepfel, L. E.; Voegelin, A.; Sander, M.; Hofstetter, T. B. Redox properties of structural Fe in clay minerals. 2. Electrochemical and spectroscopic characterization of electron transfer irreversibility in ferruginous smectite, SWa-1. Environ. Sci. Technol. 2012, 46, 9369-9377.

(46) Gorski, C. A.; Aeschbacher, M.; Soltermann, D.; Voegelin, A.; Baeyens, B.; Marques Fernandes, M.; Hofstetter, T. B.; Sander, M. Redox properties of structural $\mathrm{Fe}$ in clay minerals. 1. Electrochemical quantification of electron-donating and -accepting capacities of smectites. Environ. Sci. Technol. 2012, 46, 9360-9368.

(47) Jones, A. M.; Collins, R. N.; Waite, T. D. Redox characterization of the $\mathrm{Fe}(\mathrm{II})$-catalyzed transformation of ferrihydrite to goethite. Geochim. Cosmochim. Acta 2017, 218, 257-272.

(48) Poggenburg, C.; Mikutta, R.; Sander, M.; Schippers, A.; Marchanka, A.; Dohrmann, R.; Guggenberger, G. Microbial reduction of ferrihydrite-organic matter coprecipitates by Shewanella putrefaciens and Geobacter metallireducens in comparison to mediated electrochemical reduction. Chem. Geol. 2016, 447, 133-147.

(49) Lau, M. P.; Sander, M.; Gelbrecht, J.; Hupfer, M. Spatiotemporal redox dynamics in a freshwater lake sediment under alternating oxygen availabilities: combined analyses of dissolved and particulate electron acceptors. Environ. Chem. 2016, 13, 826-837.

(50) Lau, M. P.; Sander, M.; Gelbrecht, J.; Hupfer, M. Solid phases as important electron acceptors in freshwater organic sediments. Biogeochemistry 2015, 123, 49-61.

(51) Sander, M.; Hofstetter, T. B.; Gorski, C. A. Electrochemical analyses of redox-active iron minerals: A review of nonmediated and mediated approaches. Environ. Sci. Technol. 2015, 49, 5862-5878.

(52) Shi, Z.; Nurmi, J. T.; Tratnyek, P. G. Effects of nano zero-valent iron on oxidation-reduction potential. Environ. Sci. Technol. 2011, 45, $1586-1592$.

(53) Schwertmann, U.; Cornell, R. M. Iron Oxides in the Laboratory: Preparation and Characterization, Second, Completely Revised and Extended Ed.; Wiley-VCH: Weinheim, 2000.

(54) Shi, Z.; Zachara, J. M.; Wang, Z.; Shi, L.; Fredrickson, J. K. Reductive dissolution of goethite and hematite by reduced flavins. Geochim. Cosmochim. Acta 2013, 121, 139-154. 
(55) Mulvaney, P.; Swayambunathan, V.; Grieser, F.; Meisel, D. Dynamics of interfacial charge transfer in iron(III) oxide colloids. J. Phys. Chem. 1988, 92, 6732-6740.

(56) Mulvaney, P.; Cooper, R.; Grieser, F.; Meisel, D. Charge trapping in the reductive dissolution of colloidal suspensions of iron(III) oxides. Langmuir 1988, 4, 1206-1211.

(57) Tamura, H.; Goto, K.; Yotsuyanagi, T.; Nagayama, M. Spectrophotometric determination of iron(II) with 1,10-phenanthroline in the presence of large amounts of iron(III). Talanta 1974, 21, 314-318.

(58) Christoffersen, J.; Christoffersen, M. R. The kinetics of dissolution of calcium sulphate dihydrate in water. J. Cryst. Growth 1976, 35, 79-88.

(59) Postma, D. The reactivity of iron oxides in sediments: A kinetic approach. Geochim. Cosmochim. Acta 1993, 57, 5027-5034.

(60) Fischer, W. R. Standard potentials $\left(\mathrm{E}_{0}\right)$ of iron(III) oxides under reducing conditions. Z. Pflanzenernaehr. Bodenkd. 1987, 150, 286-289.

(61) Gorski, C. A.; Edwards, R.; Sander, M.; Hofstetter, T. B.; Stewart, S. M. Thermodynamic characterization of iron oxide-aqueous $\mathrm{Fe}^{2+}$ redox couples. Environ. Sci. Technol. 2016, 50, 8538-8547.

(62) Usman, M.; Abdelmoula, M.; Faure, P.; Ruby, C.; Hanna, K. Transformation of various kinds of goethite into magnetite: Effect of chemical and surface properties. Geoderma 2013, 197-198, 9-16.

(63) Usman, M.; Abdelmoula, M.; Hanna, K.; Grégoire, B.; Faure, P.; Ruby, C. $\mathrm{Fe}^{\mathrm{II}}$ induced mineralogical transformations of ferric oxyhydroxides into magnetite of variable stoichiometry and morphology. J. Solid State Chem. 2012, 194, 328-335.

(64) Jeon, B.-H.; Dempsey, B. A.; Burgos, W. D.; Royer, R. A. Reactions of ferrous iron with hematite. Colloids Surf., A 2001, 191, $41-55$.

(65) Stemig, A. M.; Do, T. A.; Yuwono, V. M.; Arnold, W. A.; Penn, R. L. Goethite nanoparticle aggregation: effects of buffers, metal ions, and 4-chloronitrobenzene reduction. Environ. Sci.: Nano 2014, 1, 478487.

(66) Tadanier, C. J.; Schreiber, M. E.; Roller, J. W. Arsenic mobilization through microbially mediated deflocculation of ferrihydrite. Environ. Sci. Technol. 2005, 39, 3061-3068.

(67) Stucki, J. W.; Anderson, W. L. The Quantitative Assay of Minerals for $\mathrm{Fe}^{2+}$ and $\mathrm{Fe}^{3+}$ Using 1,10-Phenanthroline: I. Sources of Variability. Soil Sci. Soc. Am. J. 1981, 45, 633-637.

(68) Stumm, W.; Morgan, J. J. Aquatic Chemistry; Chemical Equilibria and Rates in Natural Waters; John Wiley \& Sons: New York, 1996.

(69) Anslyn, E. V.; Dougherty, D. A. Modern Physical Organic Chemistry; University Science Books: Sausalito, 2006.

(70) LaKind, J. S.; Stone, A. T. Reductive dissolution of goethite by phenolic reductants. Geochim. Cosmochim. Acta 1989, 53, 961-971.

(71) Sulzberger, B.; Laubscher, H. Reactivity of various types of iron(III) (hydr)oxides towards light-induced dissolution. Mar. Chem. 1995, 50, 103-115.

(72) Suter, D.; Banwart, S.; Stumm, W. Dissolution of hydrous iron(III) oxides by reductive mechanisms. Langmuir 1991, 7, 809813.

(73) Zinder, B.; Furrer, G.; Stumm, W. The coordination chemistry of weathering: II. Dissolution of Fe(III) oxides. Geochim. Cosmochim. Acta 1986, 50, 1861-1869.

(74) Stumm, W.; Sulzberger, B. The cycling of iron in natural environments: Considerations based on laboratory studies of heterogeneous redox processes. Geochim. Cosmochim. Acta 1992, 56, 3233-3257.

(75) Torrent, J.; Schwertmann, U.; Barron, V. The reductive dissolution of synthetic goethite and hematite in dithionite. Clay Miner. 1987, 22, 329-337. 